$\mathbf{R}_{\text {ESEARCh }} \mathbf{P}_{\text {APER }} \longrightarrow$ FOOD SCIENCE

e ISSN-2230-9403 - Visit us :

www.researchjournal.co.in

Volume 9 | Issue 1 | April, 2018 | 150-155

DOI : $10.15740 / \mathrm{HAS} / \mathrm{FSRJ} / 9.1 / 150-155$

\title{
Effect of processing on the nutritional composition of ragi (Eleusine coracana)
}

\author{
Megha Bansal and Navjot Kaur
}

Ragi is millet, packed with fibre and calcium, is extremely beneficial due to its enormous health benefits. The millet is wholesome and recommended for all age groups. This study was planned to analyse the effect of processing on the nutritional composition of ragi. Raw and malted form of ragi were nutritionally analysed. Significant changes in nutritional composition of ragi were observed during processing. The raw ragi flour had good amounts of crude protein (4.6\%), crude fat (3.06\%) and crude fibre (14.8\%). Amounts of amino acids were on the higher side i.e. tryptophan $(116.77 \mathrm{mg} / 100 \mathrm{~g}$ protein), methionine $(181.56 \mathrm{mg} / 100 \mathrm{~g}$ protein) and lysine $(195.67 \mathrm{mg} / 100 \mathrm{~g}$ protein), as well as total sugars $(5.32 \mathrm{~g} / 100 \mathrm{~g})$ and starch $(0.82 \mathrm{~g} / 100 \mathrm{~g})$. Malting of ragi enhanced the crude protein $(7.11 \%)$, ash $(4.13 \%)$, tryptophan $(250.13 \mathrm{mg} / 100 \mathrm{~g}$ protein) and methionine $(351.1 \mathrm{mg} / 100 \mathrm{~g}$ protein) content. The antinutritional components reduced after the process of malting. The results revealed that malting of ragi should be done to enhance its nutritional profile and to maximize health benefits.

Key Words : Malted ragi, Processing, Proximate composition, Amino acids, Anti nutritional components

How to cite this article : Bansal, Megha and Kaur, Navjot (2018). Effect of processing on the nutritional composition of ragi (Eleusine coracana). Food Sci. Res. J., 9(1): 150-155, DOI : 10.15740/HAS/FSRJ/9.1/150-155. 